\title{
The Peculiarities of the Perception and Understanding of Sonnets Written by W. Shakespeare by the Students of the Faculty of Foreign Languages
}

\section{Особливості сприйняття і розуміння сонетів В. Шекспіра студентами факультету іноземної філології}

\author{
Nataliya Mykhalchuk ${ }^{1}$ \\ Dr. in Psychology, Professor, \\ Head of the Department \\ of Practice of English
}

\author{
Наталія Михальчук ${ }^{\mathbf{1}}$ \\ доктор психологічних наук, \\ професор, завідувач кафедри \\ практики англійської мови
}

\author{
E-mail: Natasha1273@ukr.net \\ orcid.org/0000-0003-0492-9450 \\ Researcher ID: A-9440-2019
}

\section{Olga Kryshevych ${ }^{2}$}

Ph.D. in Law, Professor Assistant
Ольга Кришевич ${ }^{2}$

кандидат юридичних наук, доцент

\section{E-mail: kryshevych.o@gmail.com orcid.org/0000-0001-6136-8106 \\ Researcher ID: F-3877-2019}

${ }^{1}$ Rivne State University of the Humanities

12, Stepan Bandera Str., Rivne, Ukraine, 33000

${ }^{2}$ National Academy of Internal Affairs,

Department of Criminal Law

$\triangle 1$, Solomenska Square, Kyiv, Ukraine, 03035
${ }^{1}$ Рівненський державний гуманітарний університет $\checkmark$ вул. Степана Бандери, 12, Рівне, Україна, 33000

${ }^{2}$ Національна академія внутрішніх справ

Соломенська площа, 1, Київ, Україна, 03035

Original manuscript received September 29, 2018

Revised manuscript accepted September 25, 2019 


\section{ABSTRACT}

The purpose of the article is to analyze the peculiarities of the perception and understanding of Sonnets written by W. Shakespeare by the students of the Faculty of Foreign Languages.

The methods of the research are: in order to study the features of perception and understanding of the absurd in the sonnets of $W$. Shakespeare we used the method of associative experiment. In our research we examined the dependence of the latent period of awareness of the absurd meaning of speech acts, depending on the nature of stimulation. For comparing we proposed to students high-frequency phrases, emotionally colored ones (chosen from the sonnets of W. Shakespeare), low-frequency statements, stylistically colored phrases, statements which include slang.

The results of the research. At the end of the procedure of the experiment, a total of 1958 verbal responses of the students were received. From them, 897 reactions are for high frequency phrases; 458 - for emotionally colored ones; 293 are for low frequency phrases; 256 - for stylistically colored ones and only 54 reactions are for slang. At the stage of the analysis of the results we arranged the groups of words depending on statistical differences in the average time of the associative reaction for each group in order from the smallest one to the largest group: 1) high-frequency and emotionally colored; 2) stylistically colored: 3) low-frequency; 4) phrases with slang.

Conclusions. It was proved that students adequately perceived and understood the emotionally colored phrases that were selected by us from W. Shakespeare's sonnets and contained explicit and implicit absurd meaning. This gives us reason to argue that these statements, with their expressive context and absurd content, in a great degree attracted students that they perceived these phrases as personally significant, experienced them in such a way that they already entered their sphere of personally significant experience.

Key words: the absurd, the absurd meaning, absurd frames, random details, archetypes, metaphorical contexts, literary denouement with the absurdly displaced center.

\section{Introduction}

The problem of the perception and understanding of novels, plays, sonnets and poetry in general isn't new in scientific literature. But when we tell about sonnets of W. Shakespeare, a lot of researchers (Shportun, 2018; Stockwell, 2002) emphasized, that they were more difficult for understanding, first of all, because of details of absurd and nonsense in their structure. As S. Freud (1952) noted in his researches that literature was rooted in the sense of independence we enjoyed. And, due to this, it was able to comprehend the limitless limits of logic. When Freud wrote his researches, he added that it was a real pleasure to hide carefully 
in an adult's life almost to the point of our disappearance, while the children found pleasure in composing words without worrying about their meaning or logical consistency. The determining factor is the fact that it is influenced by the need to be targeted in serious, adult life and, because of this, it became more important than ever before, and literature and theater have been rising to dismissal because of nonsense and, in spite of this, incomprehensible becomes understandable.

It is known that the literature of nonsense, and especially the poetry of nonsense, influenced the perception of its reader due to the logical connections between words, phrases and even sentences (Sewell, 1952). We have come up with some examples of school poetry of the nonsense of the XIII-th century, which can be considered the most ancient examples of this genre. In addition, we can be sure that meaningless of rhyme-songs were sung by children and repeated by adults from ancient times, since there was a whole magic of nonsense, and magic formulas often consisted of syllables that had preserved rhyme or rhythm till the current period of time, but had lost any meaning, which they could contain from the very beginning (Collins, 2014; Cummine, Aalto, Ostevik, Cheema \& Hodgetts, 2018). Also the same we can tell about the sonnets of W. Shakespeare, because a lot of scientists (Esslin, 1987; Shportun, 2018; Stockwell, 2002) told that these sonnets were, in a great degree, difficult to understand.

Although some issues (or trends or directions of issues) remain unsolved in the scientific literature. For example, the role of explicit or implicit absurdity in the sonnets of W. Shakespeare is not completely analyzed in details in the scientific literature, especially according to the examples of authentic texts.

Also unsolved in the psychological literature are, for example, the questions of the structure of the consciousness of a talented person, his/her framed nature, to which, according to our belief, must enter, including stable archetypal development that will enhance the content of the consciousness of the person of W. Shakespeare. In accordance with this problem, to the mind of this writer should include certain frames which explicate the ability to reproduce the absurd. After all, taking into account the theory of O. Shportun (2018), which deals with psychology and pathophysiology of humor, it becomes clear that humor is to a large extent genetically determined by the character of the person. We have to admit that not all people are capable of adequate when we tell about the 
perception of humor, some people generally do not perceive humor as a matter of fact, and, in such a way, absurdist tendencies are not peculiar and difficult in their semantic load (Koring, Meroni \& Moscati, 2018; Shigeno, 2018).

\section{Methods and methodical instrumentation of the research}

The following scientific methods were used as the basis of the research: holistic analysis of the text, problem-thematic analysis, also comparative analysis.

The following methods have also been used to study the research material: the descriptive method - in order to distinguish units that denote the category of the absurd; the method of distributive analysis for dividing the selected units (secondary segmentation) into such word forms with the purpose of their analysis, classification and interpretation for the usage of the data obtained during the formal description of the structures that denote the category of the absurd; the method of syntactic transformation - to identify those features of the structures of the absurd categories that are not explicitly available in the analyzed sentences.

As an experimental method we used an associative experiment (Tye, 1995). To compare the empirical distribution with the theoretical (normal), we used the Pearson criterion and the Kolmogorov-Smirnov criterion. In addition, the elements of quantitative analysis were used in order to determine the frequency of models of the investigated structures and their components and the characteristics of the correlation between the obtained indicators.

\section{The results of the research and their discussion}

First of all, reading Shakespeare's comedies of fun («The Taming of the Shrew», «Much Ado About Nothing») we have to say that understanding the absurdity of W. Shakespeare is largely due to the fact that Shakespeare's thought is «dissolved» in the images and situations of his plays, and it is through this he was able to comprehensively fully disclose the characters and circumstances that the images created by the author were rich and complex as the reality itself. That is why when different interpretations of Shakespeare's plays are offered, they are also 
The Peculiarities of the Perception and Understanding of Sonnets...

diverse, and sometimes contradictory, as there are thoughts of different people about the reality which is surround us.

So more and more it was understood in the world the value of W. Shakespeare, each generation in a new way comprehended his works, and every person interpreted W. Shakespeare in a new way. Deeper thoughts laid down by W. Shakespeare in his play were increasingly revealed, his artistic skill became more clearly evident.

The artistic system of Shakespeare's drama was largely based on the traditions of a national theater, but to a large extent it was depended on its inheritance to the ancient theater. The drama of classical antiquity was characterized by a strict composition of construction. In the plays of ancient authors, the action, as a rule, took place in one place and during a rather brief period, about in a week. The plot, as a rule, contained only one event, depicted without any deviations. In the tragedies of W. Shakespeare the action generally began on the eve of the solution of the conflict.

To a large extent, thanks to the presentation of the absurd, also absurd tendencies the plays of a great English writer William Shakespeare has a worldwide significance. Shakespearean genius is dear to all mankind. The world of ideas and images of humanist poets in general is enormous, and the worldwide significance of W. Shakespeare is also in realism and the nation's creativity. Thus, W. Shakespeare developed the basic principles of the Renaissance drama, his drama concept was formed on the basis of a complex synthesis of the Renaissance historiosophy and the Old Testament concept of a free human person. As a Renaissance artist, the playwright updated the person's free personality and emphasized her/his ultimate victory over the whole world.

However, in the image of W. Shakespeare a person, trying to achieve his/her goal, constantly faces opposition from the other people who nullify his/her free personality. This counteraction may be absurdly aware by another person (for example, in the «Hamlet» King Claudius deliberately acts against the prince and prevents him from implementing a plan of revenge), but also it can be unconscious (in comedies, in «Romeo and Juliet»). Then we say that the unconscious opposition represents the role of absurd randomness. The Man is powerless against the certain accident; he/she can take into account causal relationships only in the immediate proximity of himself/herself, but he/she can not 
foresee the interference of distant forces that destroy his/her life or make a chaos and feel confusion because of it.

In this absurdly hidden nature of causal relationships lies, according to W. Shakespeare, the uncertainty of human existence, which may even become tragic. This corresponds to the Old Testament concept of interference of higher, unidentified forces in a human life. Thus, the Biblical character of Abraham was carefully built by his welfare step by step, but the result of his righteous way of life was completely unforeseen for him: Yahweh demanded that he was sacrificed to Jacob. But this time the result was unexpected because Yahweh saved Isaac. On the other hand, the rule of chance can be the cause of comic disorder (as, in particular, in comedies).

In essence, Tragic and Absurd have one basis, as W. Shakespeare mean. In his comedies, as a rule, we find only one thing among comedic collisions, where events develop with dramatic acuteness («Much Ado About Nothing», «A Midsummer Night's Dream»); at the same time, comedic situations and comic characters are often used in tragedies, and some tragedies to a certain place develop under the laws of comedic conflict («Romeo and Juliet»). Some tragedies are written according to the plots of comic Italian novels («Othello»).

The structure of the dramatic story of W. Shakespeare is also rather difficult, given the practice of crossing several plot lines. Often the author applies an absurd oversleep; in particular, in «Romeo and Juliet» this is a cry of Paris to Juliet and the consent of the girl. At the same time, we know about the romance of Romeo in Rosalyn; therefore, the viewer is ready to monitor the development of these interactions. However, the true tie is only at the end of the first action; for this result the playwright introduces something like a discussion (a ball in the house of Capulet, on which the both couples have a conscious intention to meet), and it causes events in a completely different direction. But if the line Romeo - Rosalina «rolls» right after the scene of the ball, then the Paris - Juliet line continues to grow actively and ends its completion at the end of the play, when Paris dies near the crypt, protecting the honor of the bride from the rage (the last one is Romeo). So, we can talk about a certain ambiguity of the solution, which has so called «shifted center». The dramatist strives to complete the development of all story lines in about one time and spatial paradigm. 
The example of an absurd plot we also find in «Hamlet», where the appearance of a ghost is a night watch and the prince himself is associated initially with the War of Fortinbrass. The true meaning of the night event is revealed only in the last part of the 1-st action, which can be considered as a real plot. However, the line of Fortinbrass does not disappear, moreover, the appearance of Fortinbrass with the army completes the whole play.

The problem of climaxing in plays of W. Shakespeare is also uneasy. In such understanding is «Othello», where literary denouement is with the absurdly displaced center (the murder of Desdemony and the death of Othello) leads to a complex semantic climax. It's not simple just to point to the culmination of the events in «Romeo and Juliet» because here the tragic death in the crypt becomes into the image of a peculiar apotheosis of truth over the bodies of lovers. For W. Shakespeare who is a supporter of a strong monarchical power a significant number of plays ends with a solemn scene of the appearance of the lord, whose mouth proclaims truth, justice, new order. Also we can argue that for Shakespeare the accident is necessarily to enter the catharsis, which, however, also has absurd characteristics.

Consequently, thanks to the absurdity, W. Shakespeare reveals new facets, new depths and, at the same time, tragedy in Renaissance dualism. The official status of a Man W. Shakespeare considered unreal, temporary. The negative characters in his drama are people who seek to conquer or strengthen their official status. Such a life goal in the plays of W. Shakespeare is false, perverse, leads eventually to a vital defeat. In order to achieve these deceptive purpose, such people often are drown in natural feelings or sacrifice natural connections, that is, in such a way, they kill their natural essence.

Also thanks to the absurd, absurd play of words W. Shakespeare transmitted the national color of English reality, the nature of English folk culture. No one earlier could have been so colorful, with the help of absurd tendencies, had a possibility to depict the course of the history itself, to show different layers of the society in a single dynamic system. Thanks to the absurdity, Shakespeare portrayed in his writings the turning point of the era, a dramatic struggle between the Old and the New. His writings reflected the movement of history in its tragic contradictions. 
Having understood the absurd frames, explicated in the plays of W. Shakespeare, we have identified the psycholinguistic mechanisms of expressing the absurd meaning by the writer. These are such mechanisms as:

1. The explication of absurd frames which are in the consciousness of the person.

2. The expression of the image of absurd in terms of random details, archetypes, metaphorical contexts.

3. The explication of the absurdly hidden nature of causal relationships, which appear to be evident as a result of the author's usage of certain lexical units, lexical-stylistic means, etc.

4. The presentation by the author an absurd plot.

5. The presentation by the author literary denouement with the absurdly displaced center.

Consequently, it should be noted, above all, that the understanding of the absurdity arises as a result of the transforming the tense context of the work into quite obvious semantic frames. Under such conditions, the witty absurdity will include the fact that the reader first perceives a work for the truth that misleads him, and then turns into persistent absurd frames which are fixed in the consciousness of the Person. Such frames, in turn, can be understood by the reader as containing nonsense, senselessness, can lead to the creation of stable cliches (built on the principle of «game of ideas», «game of words»), which, in turn, become structural components of the consciousness of the Person.

In order to study the features of perception and understanding of the absurd in the sonnets of W. Shakespeare we used the method of associative experiment (Tye, 1995). In our research we examined the dependence of the latent period of awareness of the absurd meaning of speech acts, depending on the nature of stimulation. The experiment involved voluntary participation of 56 people of both sexes in the age from 21 to 23 years old (23 undergraduate students of the $4^{\text {th }}$ year of studying for Bachelor Degree at the university and 33 people graduated students, of the $5^{\text {th }}$ and the $6^{\text {th }}$ years of studying for Master Degree). At the time of providing our research, all participants were the students of the Faculty of Foreign Languages of Rivne State University of the Humanities.

Let us describe the procedure of organizing our research. The students were asked to answer the phrase (or phrases) as quickly as it 
was possible. This first phrase (or phrases) might be the first that came to the students' mind. In this case, the experimenter recorded the time for reaction and the phrase-association. The latent time of the associative reaction - the period from the moment of appearing the phrase (or phrases) stimulus to the moment the student responded verbally was the informative indicator of the stressfulness of the stimulus. The experiment also used an indicator of the latent period of the associative reaction, but as a marker of perceptual protection.

The objective of the research: to establish the dependence of the latent period of association (as an indicator of perceptual protection) according to the type of verbal stimulation.

The subject of the research: the dependence of the latent period of the associative reaction according to the type of verbal stimulation.

The hypothesis of the research: the effect of perceptual protection is manifested in a delay of the time of the associative reaction. In this case, the average reaction time to different groups of stimuli will be distributed in the following sequence (from the smallest to the largest ones):

1. High-frequency phrases.

2. Emotionally colored ones.

3. Low-frequency statements.

4. Stylistically colored ones.

5. Statements which include slang.

The material and equipment. For organizing the experiment, a computer program was created that allowed us to record the time from the beginning of the presentation of the stimulus on the monitor screen until the moment the student would press a certain key on the keyboard. Thus, the latent period of the reaction was measured by the chronograph of a personal computer. The stimulus material was presented to students exclusively in English, without any translation (but in this article, for better understanding expressions and phrases of the stimulus material by both English speaking and Ukrainian speaking readers, we will offer some translation, suggesting that the most of the material used by us is translated literary, not rather than by finding a direct analogue). At the same time, students had neither time nor the right to use dictionaries, and even if they did not know the translation of a particular word or phrase, they had to guess and give an associative reaction to it. In addition, choosing the stimulus material, we took into account that all 
of it contains (at least implicitly) the absurd meaning inherent either in the construction of the phrase itself or from the point of view of the contextual component. So, let us describe the stimulus material.

We considered high-frequency phrases or expressions such phrases which are well-known to students, such as they often use both at English classes and in everyday life. Here are examples of such high-frequency phrases that we used in the experiment.

- The difficult is done at once; the impossible takes a little longer - Важке робиться відразу, на неможливе йде трохи більше yacy (Free-on-line English dictionary, 2018).

- No living man all things can - Всього робити ніхто не вміє. За все береться, та не все вдається (Free-on-line English dictionary, 2018).

- Much is expected where much is given - Kомy багаmo дається, 3 того й багато питають (Free-on-line English dictionary, 2018).

- Those who think they can't are generally right - Ti, хто вважає, що вони не в змозі щось зробити, як правило, не помиляються (Free-on-line English dictionary, 2018).

- You cannot eat your cake and have it - Один пиріг двічі не їять (Free-on-line English dictionary, 2018).

- You cannot please everyone and your wife - Один чоловік усьому світові не вгодить (Free-on-line English dictionary, 2018).

- You cannot please everyone - Всім не догодии (Free-on-line English dictionary, 2018).

- Hide not your talents: they for use are given - Не приховуй своїх талантів: вони даються для того, щьоб ними користуватися (Free-on-line English dictionary, 2018).

- Genius begins great works; labour alone finishes them - Геній починає великі твори, але тільки важка прачя їх закінчує (Free-online English dictionary, 2018).

- Experience is good if not bought too dear - Досвіd - uе добре, якщо за нього не треба надто багато платити (Free-on-line English dictionary, 2018).

Emotionally colored phrases were chosen by experts from Shakespeare's sonnets. Two lecturers at the Department of Practice of English from Rivne State University of the Humanities were the experts. 
The Peculiarities of the Perception and Understanding of Sonnets...

Five emotionally colored passages from the sonnets of W. Shakespeare were chosen:

1. Sonnet LXVI:

And guilded honour shamefully misplaced,

And maiden virtue rudely strumpeted,

And right perfection wrongfully disgraced,

And strength by limping sway disabled,

And art made tongue-tied by authority,

And folly doctor-like controlling skill,

And simple truth miscall'd simplicity,

And captive good attending captain ill... (Shakespeare, 2019).

In the translation of D. Pavlychko:

На честь фальшиву, на дівочу вроду

Поганьблену, на зраду в пишноті,

На правду, що підлоті навдогоду

В бруд обертає почуття святі,

I на мистецтво під п'ятою влади,

I на талант під наглядом шиика,

I на порядність, що безбожно краде,

I на добро, що в зла за служника! (Shakespeare, 1986: 788).

2. Sonnet LXVII:

Why should false painting imitate his cheek

And steal dead seeing of his living hue?

Why should poor beauty indirectly seek

Roses of shadow, since his rose is true? (Shakespeare, 2019).

In the translation of D. Pavlychko:

Чому рум'янці в нього на виду

Відтворюе косметика брехлива?

Чи треба підмальовувать в саду

Троянду, повну істинності й дива? (Shakespeare, 1986: 789).

3. Sonnet LXXX:

Your shallowest help will hold me up afloat,

Whilst he upon your soundless deep doth ride;

Or being wreck'd, I am a worthless boat,

$\mathrm{He}$ of tall building and of goodly pride:

Then if he thrive and I be cast away,

The worst was this; my love was my decay (Shakespeare, 2019).

In the translation of D. Pavlychko: 
Суперник мій іде понад глибини, Він - корабель високий, наче дім.

А я - на мілині. Хто з нас погине?

Та щзо там шкоди в човнику малім!

Я знатиму, як прийде мить остання:

Одне і те ж - кохання і конання (Shakespeare, 1986: 792).

4. Sonnet CXXIII:

Our dates are brief, and therefore we admire

What thou dost foist upon us that is old,

And rather make them born to our desire

Than think that we before have heard them told (Shakespeare, 2019).

In the translation of D. Pavlychko:

Ми любим, щзоб усе було старим,

Бо наші дні короткі; ти, одначе,

На нас пускаєш новизну, як дим,

Щоб затуманилося око зряче (Shakespeare, 1986: 794).

\section{Sonnet CXXIV:}

If my dear love were but the child of state,

It might for Fortune's bastard be unfather'd'

As subject to Time's love or to Time's hate,

Weeds among weeds, or flowers with flowers gather'd (Shakespeare, 2019).

In the translation of D. Pavlychko:

Якби любов моя була дитям

Випадку, то, подібно до байстряти,

У бур'янах коло огидних ям

Повинна б з волі часу розквітати (Shakespeare, 1986: 795).

We considered low-frequency phrases such as ones were rarely used in English; therefore, idioms were selected as the stimulus material. Five phrases were also selected:

- To put the plough before the oxen - Робити щось шиворотнавиворот (Free-on-line English dictionary, 2018).

- To talk shop - Говорити про професійні справи підчас загальної розмови (Free-on-line English dictionary, 2018).

- To join the colors - Вступити до збройних сил (Free-on-line English dictionary, 2018).

- To go over the top - Рішуче перейти в настуn (Free-on-line English dictionary, 2018). 
The Peculiarities of the Perception and Understanding of Sonnets...

- To hunt the wrong hare - Попасти пальцем у небо (Free-online English dictionary, 2018).

Stylistically colored phrases have been suggested by us from the novel «The Adventures of Oliver Twist» by Ch. Dickens, since in this novel we deal with black humor and absurdity expressed through stylistic means:

- «Bow to the board», said Bumble; Oliver brushed away two or three tears that were lingering in his eyes and seeing no board but the table, fortunately bowed to that» (Dickens, 1991: 73).

- «...she knew what was good for children; and she had a very accurate perception of what was good for herself» (Dickens, 1991: 87).

- «As for exercise, it was nice cold weather, and he was allowed to perform his ablutions, every morning under the pump, in a stone yard, in the presence of Mr. Bumble, who prevented his catching cold, and caused a tingling sensation to pervade his frame, by repeated applications of the cane» (Dickens, 1991: 89).

- «Don't make your eyes red, Oliver, but eat your food and be thankful,» said Mr. Bumble, in a tone of impressive pomposity» (Dickens, 1991: 92).

- «Ah! I dare say he will,» replied the lady pettishly, «on our victuals and our drink. I see no saving in parish children, not I; for they always cost more to keep, than they're worth. However, men always think they know best. There! Get down stairs, little bag o' bones» (Dickens, 1991: 103).

For the purpose of presentation for students the phrases with slang, we have offered suggestions from the novel of J.D. Salinger «The Catcher in the Rye». The translation of this novel was made by O. Logvynenko.

- «You bastard, did you wake me just to ask me a dumb ques -» (Salinger, 2003: 22) - «Ти що, розбуркав мене задля своїх ідіотських...» (Salinger, 1984: 30).

- «...that Ackley was a slob in his personal habits?» (Salinger, 2003: 12) - «...що Еклі був жахливий нечупара?» (Salinger, 1984: 17).

- «I was flunking four subjects» (Salinger, 2003: 2) «я провалився з чотирьох предметів» (Salinger, 1984: 2).

- «I and Robert Tichener and Paul Campbell were chucking a football around» (Salinger, 2003: 2) - «я, Роберт Тічнер і Пол Кемблпросто перед вікнами школи ганяли м'яча» (Salinger, 1984: 2). 
- «They made me cut it out» (Salinger, 2003: 2) - «Tут мені заборонили у рот брати сигарети» (Salinger, 1984: 3).

In the research a method of simple associative experiment was used (Tye, 1995). Immediately before the start of the experimental procedure, the students were given the following instruction: «Phrases will appear sequentially on the screen. You need to respond to each definition as quickly as it is possible with the first phrase, which will maximize your understanding of the given phrase or convey its meaning». The procedure of presenting phrases is given in Table. 1.

In order to control such an important side variable, such as the speed of the motor response, pressing the key after the associative reaction by the student each time was performed by the experimenter. Therefore, the level of this side was variable and it was relatively unchanged for different states of the independent variable. The associative reaction time was fixed in ms. with the help of a computer (time was detected from the moment the student had read the phrase to the end, since the proposed phrases had been of different lengths).

The received data were processed in several stages. At the first step, mean values of reaction time and variance were calculated for each stimulus word across the entire sample of students. At the second step, the average response time for each group of stimulus phrases was calculated. To compare the empirical distribution with the theoretical (normal), we used the Pearson criterion and the KolmogorovSmirnov criterion.

At the end of the procedure of the experiment, a total of 1958 verbal responses of the students were received. From them, 897 reactions are for high- frequency phrases; 458 - for emotionally colored ones; 293 are for low-frequency phrases; 256 - for stylistically colored ones and only 54 reactions are for slang. The average values of the time of associative reactions for each phrase-stimulus are given in Table 1.

Using the indicated methods of mathematical statistics, the significance of the differences between the obtained distribution and the normal one was established. It was turned out that the obtained distributions differed from the normal one, so the method of comparing two average randomly distributed populations had been used, which had made it possible to draw a conclusion about the significance/ insignificance of the differences between the types of phrases-stimulus. 
The critical parameter (Zcr.) at a significance level of 0.01 is 2.61 . The comparison results are shown in Table 2 - Table 6.

Table 1. The average response time of students to each phrase-stimulus

\begin{tabular}{|c|c|c|}
\hline No & Stimulus material & $\begin{array}{l}\text { Average } \\
\text { time for } \\
\text { reaction } \\
(\mathrm{ms} .)\end{array}$ \\
\hline 1 & The difficult is done at once; the impossible takes a little longer & 3044 \\
\hline 2 & $\begin{array}{l}\text { And guilded honour shamefully misplaced, } \\
\text { And maiden virtue rudely strumpeted, } \\
\text { And right perfection wrongfully disgraced, } \\
\text { And strength by limping sway disabled, } \\
\text { And art made tongue-tied by authority, } \\
\text { And folly doctor-like controlling skill, } \\
\text { And simple truth miscall'd simplicity, } \\
\text { And captive good attending captain ill }\end{array}$ & 3911 \\
\hline 3 & To put the plough before the oxen & 5593 \\
\hline 4 & $\begin{array}{l}\text {...she knew what was good for children; and she had a very accurate perception } \\
\text { of what was good for herself }\end{array}$ & 4299 \\
\hline 5 & I was flunking four subjects & 6544 \\
\hline 6 & No living man all things can & 3256 \\
\hline 7 & To talk shop & 5276 \\
\hline 8 & Much is expected where much is given & 3015 \\
\hline 9 & $\begin{array}{l}\text { Why should false painting imitate his cheek } \\
\text { And steal dead seeing of his living hue? } \\
\text { Why should poor beauty indirectly seek } \\
\text { Roses of shadow, since his rose is true? }\end{array}$ & 3892 \\
\hline 10 & Those who think they can't are generally right & 3376 \\
\hline 11 & $\begin{array}{l}\text { «Bow to the board», said Bumble; Oliver brushed away two or three tears that } \\
\text { were lingering in his eyes and seeing no board but the table, fortunately bowed } \\
\text { to that }\end{array}$ & 4351 \\
\hline 12 & To join the colours & 5813 \\
\hline 13 & You bastard, did you wake me just to ask me a dumb ques... & 6712 \\
\hline 14 & You cannot eat your cake and have it & 3107 \\
\hline 15 & $\begin{array}{l}\text { Your shallowest help will hold me up afloat, } \\
\text { Whilst he upon your soundless deep doth ride; } \\
\text { Or being wreck'd, I am a worthless boat, } \\
\text { He of tall building and of goodly pride: } \\
\text { Then if he thrive and I be cast away, } \\
\text { The worst was this; my love was my decay. }\end{array}$ & 4517 \\
\hline 16 & $\begin{array}{l}\text { As for exercise, it was nice cold weather, and he was allowed to perform his } \\
\text { ablutions, every morning under the pump, in a stone yard, in the presence of } \\
\text { Mr. Bumble, who prevented his catching cold, and caused a tingling sensation } \\
\text { to pervade his frame, by repeated applications of the cane }\end{array}$ & 4821 \\
\hline 17 & To go over the top & 4923 \\
\hline
\end{tabular}


Особливості сприйняття і розуміння сонетів В. Шекспіра...

18 You cannot please everyone and your wife

19 «...that Ackley was a slob in his personal habits?»

6731

20 You cannot please everyone

21 To hunt the wrong hare

5642

22 Our dates are brief, and therefore we admire

4376

What thou dost foist upon us that is old,

And rather make them born to our desire

Than think that we before have heard them told.

23 Hide not your talents: they for use are given

24 I and Robert Tichener and Paul Campbell were chucking a football around

25 «Don't make your eyes red, Oliver, but eat your food and be thankful», said Mr. Bumble, in a tone of impressive pomposity

26 Genius begins great works; labour alone finishes them

27 They made me cut it out

28 If my dear love were but the child of state,

It might for Fortune's bastard be unfather'd'

As subject to Time's love or to Time's hate,

Weeds among weeds, or flowers with flowers gather'd

29 Experience is good if not bought too dear

$30 \mathrm{Ah}$ ! I dare say he will,» replied the lady pettishly, «on our victuals and our drink. I see no saving in parish children, not I; for they always cost more to keep, than they're worth. However, men always think they know best. There! Get down stairs, little bag o' bones

Table 2. The significance of differences between high-frequency phrases and other groups of phrases-stimulus

\begin{tabular}{l|cccc}
\hline $\begin{array}{l}\text { The groups of } \\
\text { phrases-stimulus }\end{array}$ & $\begin{array}{c}\text { Emotionally } \\
\text { colored }\end{array}$ & Low-frequency & $\begin{array}{c}\text { Stylistically } \\
\text { colored }\end{array}$ & $\begin{array}{c}\text { Statements which } \\
\text { include slang }\end{array}$ \\
\hline $\begin{array}{l}\text { Observed parameter } \\
\text { (Z observed) }\end{array}$ & 2.13 & 7.54 & 4.32 & 9.62 \\
\hline
\end{tabular}

Table 3. The significance of differences between low-frequency phrases and other groups of phrases-stimulus

\begin{tabular}{l|cccc}
\hline $\begin{array}{l}\text { The groups of } \\
\text { phrases-stimulus }\end{array}$ & $\begin{array}{c}\text { Emotionally } \\
\text { colored }\end{array}$ & High-frequency & $\begin{array}{c}\text { Stylistically } \\
\text { colored }\end{array}$ & $\begin{array}{c}\text { Statements which } \\
\text { include slang }\end{array}$ \\
\hline $\begin{array}{l}\text { Observed parameter } \\
\text { (Z observed) }\end{array}$ & 5.90 & 6.11 & 5.19 & 8.31 \\
\hline
\end{tabular}

Table 4. The significance of differences between emotionally colored phrases and other groups of phrases-stimulus

\begin{tabular}{l|cccc}
\hline $\begin{array}{l}\text { The groups of } \\
\text { phrases-stimulus }\end{array}$ & Low-frequency & High-frequency & $\begin{array}{c}\text { Stylistically } \\
\text { colored }\end{array}$ & $\begin{array}{c}\text { Statements which } \\
\text { include slang }\end{array}$ \\
\hline $\begin{array}{l}\text { Observed parameter } \\
\text { (Z observed) }\end{array}$ & 4.98 & 2.48 & 3.22 & 11.94 \\
\hline
\end{tabular}


The Peculiarities of the Perception and Understanding of Sonnets...

Table 5. The significance of differences between stylistically colored phrases and other groups of phrases-stimulus

\begin{tabular}{l|cccc}
\hline $\begin{array}{l}\text { The groups of } \\
\text { phrases-stimulus }\end{array}$ & Low-frequency & High-frequency & $\begin{array}{c}\text { Emotionally } \\
\text { colored }\end{array}$ & $\begin{array}{c}\text { Statements which } \\
\text { include slang }\end{array}$ \\
\hline $\begin{array}{l}\text { Observed parameter } \\
\text { (Z observed) }\end{array}$ & 5.46 & 3.98 & 1.15 & 9.32 \\
\hline
\end{tabular}

Table 6. The significance of differences between phrases which include slang and other groups of phrases-stimulus

\begin{tabular}{l|cccc}
\hline $\begin{array}{l}\text { The groups of } \\
\text { phrases-stimulus }\end{array}$ & Low-frequency & High-frequency & $\begin{array}{c}\text { Emotionally } \\
\text { colored }\end{array}$ & $\begin{array}{c}\text { Stylistically } \\
\text { colored }\end{array}$ \\
\hline $\begin{array}{l}\text { Observed parameter } \\
\text { (Z observed) }\end{array}$ & 6.30 & 7.44 & 10.45 & 8.24 \\
\hline
\end{tabular}

At the first stage of the analysis we'll arrange the groups of words depending on statistical differences in the average time of the associative reaction for each group in order from the smallest one to the largest group:

1. High-frequency and emotionally colored phrases.

2. Stylistically colored ones.

3. Low-frequency statements.

4. Phrases with slang.

The longest latent time of the associative reaction (among meaningful stimuli) to low-frequency phrases and statements with slang indicates the presentation of the effect of perceptual protection. This conclusion is also confirmed by the fact that the average reaction time to low-frequency phrases and statements with slang is the smallest among the categories of all stimuli.

The absence of significant differences in the average reaction time to groups of high-frequency and emotionally colored phrases does not correspond to the initial assumption. We can assume that the emotionally colored phrases that were selected by us from W. Shakespeare's sonnets and contained explicit and implicit absurd meaning, attracted students with their expressive context and absurd content, that they accepted these phrases as personally significant, experienced them in such a way that they had already entered into their sphere of personally significant experience. This can be proved by students' understanding of emotionally colored phrases which are in W. Shakespeare's sonnets. 
After reading the phrases from Sonnet LXVI, student Maxim D. gives his own understanding of it: «Despite the relish, W. Shakespeare is controlling the thrills from a moral and intellectual centre, as he conducts a satiric drive. Sensation and comic effect may break free, may be locally intense and assertive, but there is usually a connection with dominant themes, even though such connection may at times seem tenuous. The story of psychological change, the love interest, the mystery and the comedy contribute to the satire on the condition of England. The house of England is bleak, failing to the house and nourishes and keeps the life sweet. That traditional literary symbol of the house is remade».

Having read the phrases from Sonnet LXVII, student Zaryana K. gives such understanding of it: "We mark heartlessness but laugh at absurdity. The language becomes even more freely inventive, taking off into brilliant nonsense. We've to exclaim: devoid of parents, devoid of relations, devoid of flocks and herds, devoid of gold, of silver, and of precious laws».

Sonnet LXXX facilitated such understanding of it by student Oksana N.: «Coleridge once described Shakespeare's wit as the overflow of high spirits, like a man twirling his stick: W. Shakespeare combines scathing satire with such sparkling exuberance». We'll give another understanding of this text by student Christina F.: «W. Shakespeare specializes in blending, rather than striping, the pathetic and the comic, the grim and the amusing. All his sonnets are rich in such blends. The sea became ludicrous, and we observed with amusement by the heroine and the ship, but we also feel sadness»».

After reading Sonnet CXXIII, student Oleg K. expressed the following thought: «Everything noted above proves that absurd was the main means for W. Shakespeare to ridicule the English Court System».

The average reaction time for emotionally colored phrases is statistically significantly less than the average latent reaction time for low-frequency words and phrases with slang vocabulary. And although slang refers to words that carry an emotional charge, in the experimental situation that is, outside the social contexts of their usual use, is close to such words even for people who constantly use them. These words are the subject of extreme reaction.

The average reaction time to stylistically colored vocabulary is statistically significantly less than the average time of the associative 
The Peculiarities of the Perception and Understanding of Sonnets...

reaction to low-frequency words and phrases with slang vocabulary. This result disproves the original assumption. It turned out that a stimulus with semantic uncertainty causes the greatest delay of verbal association. This result (regarding stylistically colored vocabulary) is probably a manifestation of the contextual effect.

\section{Conclusions}

So, we can draw such conclusions:

1. The effect of perceptual protection can be expressed in increasing of the latent time of the associative reaction.

2. Students adequately perceived and understood the emotionally colored phrases that were selected by us from W. Shakespeare's sonnets and contained explicit and implicit absurd meaning. This gives us reason to argue that these statements, with their expressive context and absurd content, in a great degree attracted students that they perceived these phrases as personally significant, experienced them in such a way that they already entered their sphere of personally significant experience.

3. The factor of semantic uncertainty in the research of consciousness of the person is more important than the perception and understanding of negative emotional frames, semantically indefinite stimuli or low-frequency words.

\section{References}

Collins, M.X. (2014). Information Density and Dependency Length as Complementary Cognitive Models. Journal of Psycholinguistic Research, 43(5), 651-681. https:// doi.org/10.1007/s10936-013-9273-3

Cummine, J., Aalto, D., Ostevik, A., Cheema, K., \& Hodgetts, W. (2018). «To name or Not to Name: That is the Question»: The Role of Response Inhibition in Reading. Journal of Psycholinguistic Research, 47(5), 999-1014. https://doi. org/10.1007/s10936-018-9572-9

Dickens, Ch. (1991). The Adventures of Oliver Twist. London: Random House.

Esslin, M. (1987). The Theatre of the Absurd. London: David Campbell Publishers ltd. Free-on-line English dictionary. (2018). Retrieved from http://www.multitran.ru

Freud, S. (1952). Der Witz and seine Beziehung zum Unbewussten. Frankfurt: Frankfurt am Main [in German].

Koring, L., Meroni, L., \& Moscati, V. (2018). Strong and Weak Readings in the Domain and Children's Scope Assignment. Journal of Psycholinguistic Research, 47(6), 1193-1217. https://doi.org/10.1007/s10936-018-9573-8

Salinger, J.D. (2003). The Catcher in the Rye. OCR \& Spellcheck: Aerius. 
Salinger, J.D. (1984). Nad prirvoiu u zhyti [The Catcher in the Rye]. (O. Lohvynenka, Trans). Kyiv: Youth [in Ukrainian].

Sewell, E. (1952). The Field of Nonsense. London: D. Campbell Publishers ltd.

Shigeno, S. (2018). The effects of the Literal Meaning of Emotional Phrases on the Identification of Vocal Emotions. Journal of Psycholinguistic Research, 47(1), 195-213. https://doi.org/10.1007/s10936-017-9526-7

Shakespeare, W. (1986). Tvory v shesty tomakh [Plays in six volumes]. (D. Pavlychka, Trans). (Vol. 6, pp. 788-797). Kyiv: Dnieper [in Ukrainian].

Shakespeare, W. (2019). The Sonnets. Retrieved from http://www.shakespeares-sonnets. com/all.php

Shportun, O.M. (2018). Psykholohiia ta patopsykholohiia humoru: model, diahnostyka, korektsiia [Psychology and pathopsychology of humor: the model, the diagnosis, correction]. Extended abstract of Doctor's thesis. Kyiv [in Ukrainian].

Stockwell, P. (2002). Cognitive Poetics: An Intoduction. L., N.Y.: Penguin Books.

Tye, M. (1995). Ten problems of consciousness. Cambridge: MIT Press.

\section{АНОТАЦІЯ}

Метою статmі було проаналізувати особливості сприйняття і розуміння сонетів В. Шекспіра студентами факультету іноземної філології.

Методи. 3 метою вивчення особливостей сприйняття i розуміння абсурду в поезії В. Шекспіра було використано метод асоціативного експерименту. у дослідженні вивчалися залежності латентного періоду усвідомлення абсурдного змісту мовленнєвих актів залежно від характеру стимуляції. Для порівняння студентам були запропоновані високочастотні фрази, емоційно забарвлені (вибрані з сонетів В. Шекспіра), низькочастотні висловлювання, стилістично забарвлені і фрази, до структури яких входив сленг.

Результати. По завершенню процедури експерименту було отримано в цілому 1958 вербальних відповідей респондентів. 3 них 897 реакцій - на високочастотні фррази; 458 - на емоційно забарвлені; 293 - на низькочастотні; 256 - на стилістично забарвлені і тільки 54 реакції - на сленг. На етапі аналізу отриманих результатів групи слів були розташовані залежно від статистичних відмінностей величини середнього часу асочіативної реакції за кожною групою в порядку від найменшого до найбільшого: 1) високочастотні і емочійно забарвлені; 2) стилістично забарвлені; 3) низькочастотні; 4) фрази зі сленгом.

Висновки. Доведено, що студенти досить адекватно сприймали і розуміли емоційно забарвлені фрази, які були відібрані нами з сонетів В. Шекспіра і містили експліцитний або імпліцитний абсурдний сенс. Це дає нам підставу стверджувати, що ці висловлювання своїм експресивним контекстом і абсурдним змістом настільки захоплювали студентів, що вони сприймали ці фрази як особистісно значущі, переживали їх як такі, що вже входили до сфери їх особистісно значущого досвіду.

Ключові слова: абсурд, абсурдний смисл, абсурдні фрейми, випадкові деталі, архетипи, метафоричні контексти, твір із абсурдно зміщеним центром. 
The Peculiarities of the Perception and Understanding of Sonnets...

Михальчук Наталья, Кришевич Ольга. Особенности восприятия и понимания сонетов В. Шекспира студентами факультета иностранной филологии

\begin{abstract}
АННОТАЦИЯ
Целью статьи был анализ особенностей восприятия и понимания сонетов Шекспира студентами факультета иностранной филологии.
\end{abstract}

Методы. С целью изучения особенностей восприятия и понимания абсурда в поэзии В. Шекспира был использован метод ассоциативного эксперимента. В исследовании изучались зависимости латентного периода осознания абсурдного смысла речевых актов в зависимости от характера стимуляции. Для сравнения студентам были предложены высокочастотные фрразы, эмоционально окрашенные (выбранные из сонетов В. Шекспира), низкочастотные выражения, стилистически окрашенные и высказывания, которые включают сленг.

Результаты. По завершению процедуры эксперимента было получено в общей сложности 1958 вербальных ответов испытуемых. Из них 897 реакций на высокочастотные фразы; 458 - на эмоционально окрашенные; 293 - на низкочастотные; 256 - на стилистически окрашенные и только 54 реакции на сленг. На этапе анализа результатов группы слов были расположены в зависимости от статистических различий величины среднего времени ассоциативной реакции по каждой группе в порядке от наименьшего к наибольшему: 1) высокочастотные и эмоционально окрашенные; 2) стилистически окрашенные; 3) низкочастотные; 4) фрразы со сленгом.

Выводы. Доказано, что студенты достаточно адекватно воспринимали и понимали эмоционально окрашенные фразы, которые были отобраны нами из сонетов В. Шекспира и содержали эксплицитный или имплицитный абсурдный смысл. Это даёт нам основание утверждать, что эти высказывания своим экспрессивным контекстом и абсурдным содержанием настолько привлекали студентов, что они принимали эти фрразы как личностно значимые, переживали их как такие, что уже входили в их сферу личностно значимого опыта.

Ключевые слова: абсурд, абсурдный смысл, абсурдные фреймы, случайные детали, архетипы, метафорические контексты, произведения с абсурдно смещённым центром. 